\title{
Do government expenditures shift private philanthropic donations to particular fields of welfare? Evidence from cross-country data
}

\section{Published as}

De Wit, A., Neumayr, M., Handy, F., \& Wiepking, P. (2018). Do Government

Expenditures Shift Private Philanthropic Donations to Particular Fields of Welfare?

Evidence from Cross-country Data. European Sociological Review 34(1): 6-21.

\begin{abstract}
Do government expenditures shift private philanthropic donations to particular fields of welfare? We examine this association in the first cross-country study to correlate government expenditures with the level of individual private donations to different fields of welfare using the Individual International Philanthropy Database (IIPD, 2016; $\mathrm{N}_{\text {country }}=19 ; \mathrm{N}_{\text {individual }}=126,923$ ). The results of the descriptive and multilevel analyses support the idea of crosswise crowding-in; in countries where government expenditures in health and social protection are higher, more donors give to support the environment, international aid, and the arts. The level of giving to different sectors, however, is not associated with government expenditures. The results reject the crowding-out hypotheses and provide a nuanced picture of the relationship between government funding and philanthropic giving across different fields of social welfare.
\end{abstract}

Keywords: Philanthropy; Welfare states; Crowding-out; Nonprofit organizations; Government expenditures; Civic engagement; Welfare sectors.

This is the author's manuscript of the article published in final edited form as:

De Wit, A., Neumayr, M., Handy, F., \& Wiepking, P. (2018). Do Government Expenditures Shift Private Philanthropic Donations to Particular Fields of Welfare? Evidence from Cross-country Data. European Sociological Review, 34(1), 6-21. https://doi.org/10.1093/esr/jcx086 


\section{Introduction}

How is government spending associated with private donations in different fields of welfare? In an era of continued pressure on governments to decrease social welfare expenditure, the question whether private philanthropic donations can be seen as supplementary or complementary to government expenditure, gains renewed importance (Andreoni and Payne, 2011; Van Oorschot and Arts, 2005, Lecy and Van Slyke, 2013; Salamon and Anheier, 1998; Young, 2000). Previous literature hypothesizes that generous government expenditure on public goods and services discourages private initiatives to create such goods and services (e.g. Künemund and Rein, 1999; Suanet et al., 2012). This assumption is known as the "crowding-out" hypothesis (Abrams and Schitz, 1978; Andreoni, 1993; Brooks, 2004; Kingma, 1989; Roberts, 1984; Warr, 1982).

Other research, however, rejects the crowding-out hypothesis by arguing that a welldeveloped welfare state promotes civil society (Van Oorschot and Arts, 2005). It posits that generous government expenditures encourage private engagement in the form of philanthropic contributions of money and time (Anheier and Toepler, 1999; Khanna and Sandler, 2000: 1544; Rose-Ackerman, 1981); and is referred to as the "crowding-in" hypothesis.

Despite a large number of empirical studies studying this relationship the debate is still unsettled. Systematic literature reviews show that estimates of the effects of government expenditures on philanthropic giving are widely disparate. They are context sensitive, or depend on the nature of the government expenditures and on the fiels of welfare involved (De Wit and Bekkers, 2017; Lu, 2016). Also, the large majority of studies refer to data from the U.S., and less is known about the relationship in countries with different welfare-state traditions (De Wit, 2016; Bekkers, 2016). Few studies have investigated the crowding-out hypothesis across countries. 
Due to the lack of available datasets, these studies only examined measures on the decision to give or not (Bredtman, 2016; De Wit, 2016; Einolf, 2017; Gesthuizen et al., 2008; Pennerstorfer and Neumayr, 2017), or an aggregate measure of private nonprofit revenues (Sokolowski, 2013). To study how individual giving responds to government programs, information about the individual level of donations is required. Furthermore, many empirical studies examine aggregate measures of both, government funding and individual donations, and it is unlikely that a relationship is unidirectional across all fields of welfare which are supported by government (Brooks, 2004, p. 173; Khanna et al., 1995; Khanna and Sandler, 2000; Lu, 2016).

This study is the first that examines the relationship between government expenditures and the level of individual private philanthropic giving in different fields of welfare. The relationship we question is: To what extent is government spending associated with philanthropic donations? Using a new cross-country database, we are able to explore the association of government expenditure with (a) both the incidence and level of individual philanthropic donations, for (b) different welfare subsectors and (c) across 19 countries with a large diversity of government expenditures on welfare.

After examining the relationship between government expenditure and private giving across 19 countries, we test the crowding-out hypothesis for different fields of welfare to understand how government expenditure may result in either crowding-out or crowding-in of private donations across sectors. We also examine "crosswise crowding-in": whether increases in government expenditure in one field may lead to increases of individual donations in other areas. 


\section{Theory}

\section{Crowding-out and crowding-in}

The central argument in the crowding-out debate is that public initiatives discourage private initiatives, suggesting that increases or decreases in government expenditure may persuade donors to decrease or increase respectively, their own contributions - to keep contributions to the public good constant. This assumption has been studied extensively from different disciplinary views, including economics and sociology.

The crowding-out assumption follows a rational choice perspective supposing that donors gain utility from contributing to the public good (De Wit et al. 2017). Individual contributions to the public good can be made either mandatory, through government taxes, or voluntarily by philanthropic donations to nonprofit organizations providing that public good. If people are assumed to be purely altruistic and only care about realizing the public good, then increases in tax-financed government spending leads to a concomitant reduction of private donations, thereby keeping the total individual contribution (voluntary and involuntary) at the same level (Roberts, 1984; Warr, 1982). This assumption suggests a full crowding-out: that an increase or decrease in public expenditures by one dollar persuades purely altruistic donors to decrease or increase, respectively their own philanthropic contributions by one dollar (Brooks, 2004: 168; Payne 1998: 324).

Another explanation for crowding-out suggests that donors hesitate to make donations to organizations receiving government subsidies, in contexts wherein such organizations are seen either as not viable, or as the long arm of the government (Brooks, 2004: 172). Scholars also suggest organizations receiving government subsidies, decrease their fundraising efforts among 
the public, which result in decreased individual donations (Andreoni and Payne, 2011; Khanna and Sandler, 2000: 1545).

There are arguments to expect partial rather than a full crowding-out. If individuals' are not pure altruists and their motivations to give include private benefits such as the joy of giving, enhancing their reputation, or conforming with social norms or social pressure (Bekkers and Wiepking, 2011), they will give regardless of who else contributes to the public good. To the extent that donors derive such private benefits from the act of donating, their donations are less likely to be responsive to changes in contributions from a third party, such as other donors or the government (Andreoni, 1990; Payne, 2009).

In contrast, the assumptions of crowding-in rely on the signaling value of government expenditure to imply a positive association between public and private expenditures. Donors generally prefer to give to organizations that are well-established, which they perceive as being trustworthy especially when donors face information uncertainty. Government subsidies, in some contexts, are seen as a "seal of approval" of the nonprofit organization (Handy, 2000; Schiff, 1990). In addition, nonprofits may gain significant scaling advantages in their operations due to government support, which might increase their scope and effect, thereby motivating donors who care about impact of their contributions (Anheier and Toepler, 1999; Khanna and Sandler, 2000: 1544; Rose-Ackerman, 1981).

Furthermore, a positive correlation between government expenditures and philanthropic giving is expected by (neo)institutionalist theories, which posit that people adopt values and norms from the institutions surrounding them (Rothstein, 1998; Ingram and Clay, 2000). In this literature, attitudes towards social policies are shaped by the way a welfare state is structured (Arts and Gelissen, 2001; Jæger, 2006). Some countries prefer to spend more on health care, 
education, and other social issues (Baumol, 1996), and it could be that generous and universal welfare states "socialize" people to be more benevolent. Hence, people in generous welfare states would develop stronger pro-social values that encourage philanthropy.

The causal relationships between social values, welfare state generosity and philanthropy are hard to disentangle. If the median voter theorem holds, political outcomes are in line with preferences at the center of the electorate's political spectrum, then the choices in welfare-state spending expresses social values. If philanthropic giving is partly an expression of similar values, it is reasonable to assume that government expenditures and philanthropic giving will be positively correlated.

The majority of prior studies examining associations between private and public spending find some form of partial crowding-out, meaning that a dollar of government grants crowds-out donations by less than a dollar (Brooks, 2004: 173) while other studies find no significant relationship (Brooks, 1999), and some studies find a crowding-in effect, i.e. that the level of government grants is positively correlated with private donations (Andreoni and Payne, 2011; Hughes and Luksetich, 1999; Payne, 1998). A recent meta-analysis that systematically reviews previous studies on crowding-out shows that the results are strongly shaped by methods used; for example, in experimental studies a one dollar increase in government expenditures is associated with an average decrease of about 0.64 dollars, while non-experimental data analyses find a crowding-in effect of about 0.06 dollars on average (De Wit and Bekkers, 2017).

The vast part of the empirical literature is based on within-country variance in government spending, and has not yet addressed questions about differences between countries. Those studies that have examined previous cross-country studies find either positive correlations or no statistically significant relationship between government expenditures and philanthropic 
donations (De Wit, 2016; Einolf, 2017; Gesthuizen et al., 2008; Nguyen, 2015; Pennerstorfer and Neumayr, 2017; Sokolowski, 2013). Some cross-country studies examine only Western countries (De Wit, 2016; Gesthuizen et al., 2008; Pennerstorfer and Neumayr, 2017), and it could transpire that these effects may not apply to other non-Western welfare state contexts. Using broader samples of developed and developing countries, both Sokolowski (2013) and Einolf (2017) find positive correlations across the board. However, these two studies show correlations only based on aggregate country-level statistics of individual giving behavior, which makes them vulnerable to the ecological fallacy (Piantadosi et al., 1988).

In sum, different theoretical arguments lead to predictions of crowding-out or crowdingin and the following hypotheses:

Hla: Crowding-out hypothesis: Higher levels of total government expenditures are associated with lower incidence of giving and lower levels of private donations across nations.

H1b: Crowding-in hypothesis: Higher levels of total government expenditures are associated with higher incidence of giving and higher levels of private donations across nations.

\section{Effects for different fields of welfare}

The crowding-out and crowding-in arguments are usually studied based on a donor's total giving, however, there is reason to assume that changes in government expenditure affect private donations to various fields of welfare differently. Use of aggregated data may conceal or heighten different crowding-out effects in different sectors. For example, an aggregate finding of significant crowding-out does not preclude the possibilities that in one area donations have been 
completely crowded-out while in the other area there is partial crowding-out and in a third area there is no impact of increases in government expenditures, or even a partial crowding in.

It may be expected that crowding-out is more likely in the area of social welfare when donors and government compete to provided similar public goods (Stadelmann-Steffen, 2011). In addition, when public service delivery is complex and target groups are heterogeneous, governments may leave service provision to nonprofit organizations, thus making crowding out more likely (Young, 2000).

However, in the areas of environment, the arts or international aid, philanthropic donors are less likely to be discouraged by government expenditures. In these sectors, the public goods produced are more akin to common goods to which value is added by enjoying directly or indirectly (arts, reduction of poverty, clean environment, etc.) or through their provisioning (Klamer, 2004). As such, donating to the fields of arts, environment and international aid may be considered more of an expression of one's values rather than a contribution to a public good in the standard economic sense, making them less susceptible to crowding out, and more to crowding-in.

There is some empirical evidence that the relationship between government expenditures and philanthropic donations varies across welfare areas. In a systematic literature review Lu (2016) shows that government expenditures and philanthropic donations are generally negatively related in the field of human services, while they are positively related in the fields of health and the arts. In his cross-national study, Sokolowski (2013) found crowding-in for social services, health and education, but no effect in other fields. Empirical analyses on volunteering show that government expenditures discourage voluntary participation in social services and education, but 
stimulate participation in recreation and culture (Day and Devlin, 1996; Stadelmann-Steffen, 2011).

Regarding differences between fields of welfare, we formulate the following hypothesis: H2: Social welfare crowding-out hypothesis: Higher levels of government expenditures are most strongly associated with lower incidence of giving and lower levels of private donations in the fields of social services and health.

\section{Effects between fields of welfare}

Based on the empirical evidence showing that changes in government expenditures affect private donations to different fields of welfare differently (Brooks, 2004: 173; De Wit and Bekkers, 2017; Lu, 2016), we argue that expenditures in one field of welfare may be associated with increases in philanthropic giving to other fields in welfare, with the aggregate level of giving remaining constant. This effect has been labelled "philanthropic displacement" (Sokolowski, 2013) or “cross-wise crowding-in" (Pennerstorfer and Neumayr, 2017). Underlying this assumption is the argument that people are impure altruists who have preferences for public good provision in more than one subsector. If multiple public goods have value in the eyes of donors, higher government support to one fields could lead donors to decrease donations to this field, but increase donations to other areas. This is also a reasonable assumption if we believe that individuals have a philanthropic budget, or a mental account for philanthropic giving (Thaler, 1999).

Supporting the notion of philanthropic displacement, Sokolowski (2013) notes that high levels of government expenditures in the "service" sectors of education, health, or social assistance lead to higher private donations in fields like arts and entertainment, human rights, 
environmental issues, and religion. Based on similar grounds, Pennerstorfer and Neumayr (2017) argue that when public funding covers core-welfare fields, individuals may not necessarily reduce total giving, but instead donate to other related welfare issues, such as international aid. Results of a historical analysis on private donations in Sweden concur with these findings, concluding that increases in welfare state expenditure do not dampen private initiatives per se but rather displace civic engagement, resulting in higher levels of private giving in other fields (Vamstad and Von Essen, 2013).

We thus hypothesize:

H3: Crosswise crowding-in hypothesis: Higher levels of government expenditures in social services and health are associated with higher incidence of giving and higher levels of private donations to environment, international aid and arts and culture.

\section{Data}

We use data from the Individual International Philanthropy Database (IIPD, 2016), a novel dataset composed of synchronized and merged micro-level datasets on philanthropic giving from multiple countries. It includes data on 126,923 respondents from 19 countries, covering Australia (Lyons and Passey, 2007), Austria (Neumayr and Schober, 2009), Canada (CSGVP, 2004), France (Giving France, 2009), the Netherlands (GINPS05, 2006), the United Kingdom (Low et al., 2007), the United States (Wilhelm et al., 2005), Norway (Wollebæk and Sivesind, 2010), Finland (Auttaminen 2008), Mexico (ENAFI, 2005), South Korea (The Beautiful Foundation, 2006), Japan (Japan Fundraising Association, 2010), Indonesia (Strauss et al., 2009), Taiwan 
(TSCS, 2009), Israel (Haski-Leventhal et al., 2011), Ireland (HBS, 2005), Russia (CSCSNS, 2010), Germany (SOEP, 2011; Wagner et al., 2008), and Switzerland (Stadelmann-Steffen et al., 2007). Compared to other existing cross-country datasets on individual donations (e.g. European Social Survey 2002 (ESS 2002), Eurobarometer 2004 (European Commission 2012), Gallup World Poll (CAF 2017), the IIPD has the advantage of containing information not only on the incidence of giving, but also on the level of giving. All data pooled in the IIPD stem from (a) national representative surveys (b) that deploy established modules to prompt for philanthropic donations and (c) include a certain set of individual level characteristics. ${ }^{1}$ The datasets included in the IIPD have been collected between 2004 and 2010. ${ }^{2}$ From the descriptive statistics in Table 1 it can be seen that $63 \%$ of the respondents donate to philanthropic causes across all countries.

\section{[TABLE 1]}

\section{Dependent variables}

The incidence of giving, is the binary measure of whether an individual gives to a philanthropic organization or not. The level of individual philanthropic donations, the amounts donated, are calculated in 2012 US dollars. The sample is restricted here to individuals who indicated that

\footnotetext{
${ }^{1}$ While all surveys pooled meet these criteria, research on private philanthropy is sensitive to methodology and measurement issues (Hall 2001; Kennedy and Vargus 2001; Rooney et al. 2001; Wilhelm 2007).This particularly refers to the length of the module prompting for giving (solely one question or a 'method'- or 'area'- module), the period of time the prompt refers to and the type of data collection (Rooney et al. 2004, Bekkers and Wiepking 2006, Kirsch et al. 2001). While all surveys (except two) included in our data have used area-modules to prompt for donations, and most of them refer to the previous year in their prompts, the method of data collection (e.g. computer assisted phone interviews, computer assisted personal interviews or computer assisted survey interviews) differs across the surveys. More detailed information on this is provided in the documentation of the IIPD (Wiepking and Handy, 2016).

${ }^{2}$ The years of surveys in different countries are as close to each other as data availability allowed for.
} 
they give, and non-donors are excluded by listwise deletion. The average yearly amount donated is USD 550, which is strongly influenced by outliers at the top of the distribution. While total amounts donated to nonprofit organizations are available for all countries, for a smaller number of countries we were able to distinguish the amounts donated in the sectors (1) environment and animals, (2) arts and culture, (3) education and research, (4) international (relief), (5) social services/welfare and (6) health. Donations are strongly skewed, so large donations would have a disproportionate influence on the regression results. If government expenditures were to have a different effect on donations at the very top of the distribution than they have on the bottom and the middle of the distribution, this would strongly bias the results. For the graphical presentation of the country averages, the amounts are "Winsorized" for each country, which means that the top $1 \%$ of the distribution is set to the border of the $99^{\text {th }}$ percentile, making the average less sensitive to outliers (Tukey, 1962). For the regression models, we take the natural logarithm of the amounts as dependent variables (we calculate the log of the total amount and the log of the amounts in each sector separately).

\section{Country-level predictor variables}

Data on government funding are adopted from the IMF's Government Finance Statistics. The numbers for Korea do not appear in the IMF data and are adopted from the OECD, which uses the same operationalization. We use expenditures in the year 2003, so that the data reflect government spending preceding the measurement of philanthropic giving across all countries. Expenditures in the local currency are calculated in US Dollars using the exchange rates as of January 1, 2003 and are divided by the population in order to have the expenditures per capita. This broad measure of government expenditures reflects the size of welfare state efforts in 
different domains, which not only affect the direct funding of nonprofit organizations but also the broader social needs in the areas in which they are working. Besides total government expenditures, we use expenditures in different fields of welfare as defined in the Classification of Functions of Government (COFOG). We adopt IMF statistics on government expenditures to (a) environment protection, (b) education, (c) social protection and (d) health, which we match with giving in sectors 1, 3, 5 and 6, respectively. Government expenditures are divided by 1,000 in order to use measures of comparable range.

Both philanthropy and government efforts might be driven by a country's economy. Therefore, we take GDP in US Dollars per capita (divided by 1,000 ) as a control variable also adopted from the IMF Government Finance Statistics. Control variables at the individual level include age, education, gender, marital status and the natural logarithm of income in US Dollars. In the regression analyses, respondents with missing values on any of these variables are excluded through listwise deletion.

\section{Analytical strategy}

We explore the data to test our theoretical ideas as outlined in the previous section in two ways. First, we graphically explore our data, examining the correlation between government expenditures and aggregated average philanthropic donations. The average philanthropic donation per country is calculated based on both donors and non-donors, whose donation value is 0. Second, we run multilevel regression analyses to examine contextual effects while controlling for individual characteristics and allowing slopes to vary across countries.

The decision to give or not may differ from the decision how much to give. For example, financial considerations are likely to be more decisive for amounts donated than for the decision 
to make a donation (Petrovski, 2017). Therefore, we deploy separate multilevel Probit regression models on the probability to donate and multilevel linear regression models on the amount donated conditional on donating.

In the analyses of total giving and total government expenditures, we take the sum of donations to different sectors for each respondent. Respondents are clustered in countries, so random intercepts are added when estimating the association between government expenditures and philanthropic donations. For the probability to donate and the amount donated, respectively, the following multilevel Probit regression model and multilevel linear regression model are deployed:

$$
\begin{aligned}
& P\left(Y_{i j}\right)=\beta_{0}+u_{0 j}+\beta_{1} G_{j}+\beta_{2} C_{j}+\beta_{3} I_{i}+\varepsilon_{i j} \\
& \text { and } \\
& \ln \left(Y_{i j}\right)==\beta_{0}+u_{0 j}+\beta_{1} G_{j}+\beta_{2} C_{j}+\beta_{3} I_{i}+\varepsilon_{i j}
\end{aligned}
$$

in which $\mathrm{Y}$ is the likelihood of giving of respondent $i$ in country $j$ in (1) and the amount donated by respondent $i$ in country $j$ in (2); $\mathrm{u}_{0}$ is the country-specific intercept; $\mathrm{G}$ is government expenditures in US Dollars per capita divided by 1,000; $\mathrm{C}$ is the control variable on the country level, GDP per capita divided by 1,000 ; and I refers to the individual control variables. Because the natural logarithm of the amounts donated are used, the regression takes a log-linear form here. 
For the analyses on giving in different fields of welfare, a dataset is constructed in which the units of analysis are combinations of respondents and sectors. ${ }^{3}$ Every sector in each country is treated as a unique cluster for which random intercepts are added:

$P\left(Y_{i j s}\right)=\beta_{0}+u_{0 j s}+\beta_{1} G_{j s}+\beta_{2} C_{j}+\beta_{3} I_{i}+\varepsilon_{i j s}$

and

$$
\ln \left(Y_{i j s}\right)=\beta_{0}+u_{0 j s}+\beta_{1} G_{j s}+\beta_{2} C_{j}+\beta_{3} I_{i}+\varepsilon_{i j s}
$$

in which Y is the likelihood of giving of respondent $i$ to sector $s$ in country $j$ in (3) and the amount donated by respondent $i$ to sector $s$ in country $j$ in (4); and $\mathrm{u}_{0}$ is the country-sector specific intercept.

All Probit and linear regression analyses are conducted with the R statistical software.

There is an ongoing debate about the problems associated with multilevel models in comparative research (Bryan and Jenkins, 2016). With a number of countries below 20, we should be cautious with strong conclusions that hold for the total population of countries. The results can be taken as a first attempt to explore cross-country differences in the relationship between government expenditures and philanthropic giving.

\section{Results}

\footnotetext{
${ }^{3}$ Note that individuals can donate to multiple sectors and therefore appear in the data more than once. Adding random intercepts for each respondent would make the model almost unidentifiable and does not lead to substantially different results.
} 


\section{Aggregate giving}

Figure 1 plots the average amount donated per country with total government expenditures as US Dollars per capita (upper panel) and as percentage of GDP (lower panel). In Indonesia, Russia, Mexico, Taiwan and Korea, countries with relatively low government spending per capita, donations are low too. The United States and the United Kingdom have moderate government spending and relatively high donations. The average amount donated in the US and the UK is higher than in countries with high government spending per capita, like Switzerland and Norway. The correlation between amounts donated to philanthropic causes and government expenditures in USD per capita is $r=0.17(n=128,505, p<0.01)$ in the total sample, and the correlation between amounts donated and government expenditures as percentage of GDP is $r=$ $0.04(n=128,505, p<0.01)$. Note that correlations among individual-level data points are slightly different from correlations on the country level. When we would look at country averages rather than micro-level data, the correlations are $r=0.17(n=19, p=0.49)$ and $r=0.02$ $(n=19, p=0.93)$, respectively.

Models 1 to 3 in Table 2 provide a more advanced statistical test of this relationship using probit and linear multilevel regression models. Intra-class correlations (Rho) from empty models (not shown) indicate that about $8 \%$ of the variance in the likelihood to donate and $41 \%$ of the variance in the amounts donated can be explained by country level characteristics. The left panel displays results of Probit models on the likelihood to be a donor. There is no significant association between government expenditures and the likelihood to donate, with the coefficient being $B=.04$ in the model with full individual-level controls. The right panel displays the coefficients from linear models on the amount donated. Model 1 shows a positive correlation between government expenditures and donations. When controlled for GDP, which is positively 
correlated with both variables of interest, the association becomes negative and non-significant (Model 2). A strong economy enables both extensive government spending and generous philanthropic giving, so the correlation in Model 1 is a spurious one. Adding individual-level controls makes the main effect less strongly negative (Model 3). The coefficient is $B=-.05$, which means that a USD 1,000 increase in government expenditures is associated with a 5\% decrease in amount donated, albeit non-significant. Thus, neither H1a nor H1b is supported by our data.

\section{[FIGURE 1]}

\section{[TABLE 2]}

\section{Giving to different fields of welfare}

How is government spending in a certain field of welfare related to philanthropic giving in the same field? Figure 2 shows a scatter plot in which each point is a country-sector combination, with the average amount donated in this sector on the y-axis and the government spending in the same sector on the $\mathrm{x}$-axis. Both government spending and philanthropic donations are relatively low in the environment sector. In some sectors, there is high government spending and low donations like in the social sectors in the Netherlands, France and Norway. In other sectors, low government spending is related to high donations like the health sector in Canada, the educational sector in Australia, and the social sector in the US. Donations and government expenditures in different fields of welfare correlate positive, $r=0.07(n=157,014, p<0.01)$ both when taking government expenditures per capita and when looking at government expenditures as percentage of GDP. 
Table 3 provides a more systematic test of the association. Across all sectors, government expenditures are positively associated with the likelihood of donating, which is statistically significant ( $\beta=.13$ in a model with full individual-level controls). Model 4 adds interactions with sectors, which are all statistically significant. The relationship with the probability of giving is most strongly positive for government expenditures on environment. The interaction terms of health and social services with government expenditures are most strongly negative, which is in line with $\mathrm{H} 2$ on social welfare crowding-out.

The right panel of Table 3 shows coefficients of the relationships with the amount donated. Government expenditures and donations are negatively associated, but this is not statistically significant. The coefficient is $\beta=-.07$ in the model with full controls, which is equivalent to a decrease of $7 \%$ in donations with every USD 1,000 increase in government expenditures. The relationship is less strongly negative in the fields of social services and health, which is opposite of the expectation in the social welfare crowding-out hypothesis $\mathrm{H} 2$. None of the interaction terms, however, are statistically significant.

\section{[FIGURE 2]}

[TABLE 3]

\section{Effects between fields of welfare}

Next, we look at the argument of crosswise crowding-in, which states that government funding of core welfare state issues drives donations towards other sectors. Figure 3 plots social protection and health expenditures with philanthropic giving to nonprofits in the fields of social services and health (red dots) and environment, international relief, and arts and culture (blue 
dots). We would expect that government expenditures for social protection and health are negatively related to donations in the field of social services and health but positively related to donations in the other fields. There seems to be some empirical support for this argument. Countries with high domestic social welfare expenditures tend to have lower donations to social services and health but higher donations to sectors like international aid and environment.

Table 4 provides a statistical test of this crosswise crowding-in. Here, we take donations to environment, arts and culture, and international aid as the dependent variable. Health and social protection expenditures are positively associated with the likelihood to donate to environment, arts and culture, or international aid ( $\beta=.15$ in a model with full controls), which is in line with $\mathrm{H} 3$ on crosswise crowding-in. The amount donated to these fields, however, is not significantly affected ( $\beta=-.02$ in the full model). This suggests that stronger social welfare programs may drive donors towards the environment, arts and culture, or international aid, but do not lead to higher amounts donated to those areas, providing no support for $\mathrm{H} 3$.

\section{[FIGURE 3]}

\section{[TABLE 4]}

\section{Robustness analyses}

We check for robustness of our results in three ways. First, we re-run each model excluding one country, or a cluster of countries at the time, because one influential cluster can drive the results in a certain direction. In our data, the UK and especially the USA seem to be influential cases in the Probit models on the likelihood to donate. Among countries other than the USA and the UK there is a positive correlation between government expenditures and philanthropic giving at the 
country level $(\beta=0.087, p<.05)$, only a weak correlation on the country-sector level $(\beta=0.107$, $p=\mathrm{ns})$, and no evidence of crosswise crowding-in ( $\beta=0.009, p=\mathrm{ns})$.

Second, in order to examine whether our choice to take the natural logarithm of the amounts donated affects the results, we also deployed linear regression models on the amounts donated in US Dollars, Winsorized at 99\%. These regression models yield similar results as the log-linear models indicating that government expenditures are not significantly associated with levels of philanthropic donations.

Third, we use a different measure to account for a country's economy. Because the survey data are collected in different years, the economic recession could have influenced levels of donation. Therefore, we re-ran each model twice, each time with either levels of unemployment in 2003 or the change in unemployment from the year preceding the survey to the year of the survey as control variable. These models do not yield substantially different results.

\section{Discussion and conclusion}

This paper contributes to the literature on different aspects of civic participation in the welfare state by exploring government spending as a correlate of philanthropic giving. Using a novel cross-country dataset, it is the first comparative analysis that (a) relates government spending to individual amounts donated and (b) is able to examine correlations in a number of specific fields of welfare where different relationships may exist. We tested our hypotheses in multilevel regression models controlling for a country's economy and individual characteristics. 
Overall, government spending and philanthropic giving is most likely to go hand in hand. While the relationship is not statistically significant on the aggregated country level, we find that government expenditures in specific fields of welfare are likely to go together with a large proportion of donors, even when controlling for GDP and individual-level controls. This confirms earlier findings with cross-national datasets on the likelihood to donate (De Wit, 2016; Pennerstorfer and Neumayr, 2017).

Our analysis goes a step further, though, showing that the relationship between government spending and giving depends on the field of welfare studied. There is stronger crowding-in in the field of education and research, and, most strongly, in environment. In the social services and health areas, on the other hand, government spending does not strongly affect the number of donors.

The study also provides evidence for the hypothesized crosswise crowding-in. Government expenditures in the areas of social services and health are associated with a higher number of donors in environment, arts and culture, and international aid, suggesting that high levels of social welfare spending in core-welfare fields drives donors towards other areas. This finding supports prior research (Pennerstorfer and Neumayr, 2017; Sokolowski, 2013) and the idea of donors as impure altruists.

A substantial contribution of this study is the finding that, at least in this sample of countries, the amounts donors give to philanthropic causes are not associated with government spending. There is no significant relationship in a model with macro- and micro-level control variables when looking at total giving, nor is there any evidence of correlations in specific fields of welfare - and this has never been studied before. If there would have been evidence for levels of philanthropic giving to be crowded out by welfare state efforts, this would have supported 
arguments that private donations act as a substitute for government expenditures. It would be interesting to see the association between government support and donations in other contexts than the countries included in this study. Yet based on the current results, there is no reason to believe that governments and philanthropic spending are competitive.

An explanation for our findings might be that individuals have a more or less fixed budget for philanthropic giving (Thaler, 1999). In situations of low government funding, increasing total donations is not an option because that would exceed the household budget that is reserved for philanthropic giving. Within that budget, however, donors may choose their preferred philanthropic cause based on what they think is necessary and worthy. High government expenditures in social protection and health makes donations in these fields less urgent, so more donors will choose organizations in the fields of environment, culture and international aid instead of social service organizations. More research is needed to test such explanatory hypotheses.

Despite the contributions this study makes, it has some limitations. First, the use of crosssectional data with 19 countries has some weaknesses. The results are hardly generalizable and one or a few exceptional countries can drive the results in a certain direction. The robustness checks showed that the United States and the United Kingdom are influential countries in our sample. Second, the database we used consists of national surveys that have been pooled in order to conduct cross-sectional analysis, an approach used for exploring questions that otherwise could not be studied due to lack of data (see van Tubergen et al. 2004 for another example). Though all surveys included in the IIPD are nationally representative, differences between countries should be interpreted with caution. Different sampling methods (Abraham et al., 2009) and questionnaires (Bekkers and Wiepking, 2006; Rooney et al., 2004) may lead to differences 
in estimated donations, which might explain a part of the variance between countries. Third, it is difficult to deduce conclusions about the direction of causality. Both government support and philanthropic donations might be driven by the same underlying variables, which produce upwardly biased estimates. Previous studies dedicated a lot of effort to reduce this bias (Payne, 2009), although a meta-analysis did not find systemically lower estimates with techniques that account for endogeneity and omitted variable bias (De Wit and Bekkers, 2017).

We are very well aware of the problems associated with cross-sectional research and multilevel analyses with a low number of clusters. However, the role of philanthropy in different welfare states is too important to neglect.

In conclusion, our results reject the hypothesis of governments and philanthropic donations as substitutes. The association between government expenditures and the percentage of donors is robustly positive, and the magnitude of giving to different sectors is not crowded out by government spending. The different effects found for the various fields of welfare showed that the capability and willingness of citizens to engage in voluntary private funding differs between types of public goods. Further research thus needs to differentiate between welfare areas when examining the question of crowding-out and crowding-in as different mechanisms are at play here. Overall, by informing the debate about the role of philanthropic donations in light of changing government support, our findings suggest there is reason to be optimistic about productive government-nonprofit collaborations. 


\section{References}

Abraham, K.G., Helms, S. and Presser, S. (2009). How Social Processes Distort Measurement: The Impact of Survey Nonresponse on Estimates of Volunteer Work in the United States 1. American Journal of Sociology, 114(4), 1129-1165.

Abrams, B.A. and Schitz, M.D. (1978). The 'crowding-out' effect of governmental transfers on private charitable contributions. Public Choice, 33(1), 29-39.

Andreoni, J. (1990). Impure Altruism and Donations to Public-Goods - a Theory of Warm-Glow Giving. Economic Journal, 100(401), 464-477.

Andreoni, J. (1993). An Experimental Test of the Public Goods Crowding-Out Hypothesis. American Economic Review, (83)5, 1317-1327.

Andreoni, J. and Payne, A.A. (2011). Is crowding out due entirely to fundraising? Evidence from a panel of charities. Journal of Public Economics, 95(5-6), 334-343.

Anheier, H.K. and Toepler, S. (1999). Philanthropic Foundations: An International Perspective. In: Anheier, H.K. and Toepler, S. (Eds.), Private Funds, Public Purpose: Philanthropic Foundations in International Perspective. New York: Kluver Academic/Plenum Publishers, pp. 3-23.

Arts, W. and Gelissen, J. (2001). Welfare States, Solidarity and Justice Principles: Does the Type Really Matter? Acta Sociologica, 44(4), 283-299.

Auttaminen (2008). Auttaminen. [machine-readable datafile]. Pessi, Anne-Birgitta, Grönlund, Henrietta. [principle investigators]. Helsinki: University of Helsinki [distributor].

Baumol, W.J. (1996). Children of Performing Arts, the Economic Dilemma: The Climbing Costs of Health Care and Education. Journal of Cultural Economics, 20(3), 183-206. 
Bekkers, R. (2016). Regional Differences in Philanthropy. In: Harrow, J., Jung, T. and Phillips, S. (Eds.), Routledge Companion to Philanthropy. London: Routledge, pp. 124-138.

Bekkers, R. and Wiepking, P. (2006). To Give or Not to Give, That Is the Question: How Methodology Is Destiny in Dutch Giving Data. Nonprofit and Voluntary Sector Quarterly, 35(3), 533-540.

Bekkers, R. and Wiepking, P. (2011). A Literature Review of Empirical Studies of Philanthropy: Eight Mechanisms that Drive Charitable Giving. Nonprofit and Voluntary Sector Quarterly, 40(5), 924-973.

Bredtmann, J. (2016). Does Government Spending Crowd Out Voluntary Labor and Donations? IZA World of Labor Working Paper. Bonn: IZA.

Brooks, A.C. (1999). Do Public Subsidies Leverage Private Philanthropy for the Arts? Empirical Evidence on Symphony Orchestras. Nonprofit and Voluntary Sector Quarterly, 28(1), 3245.

Brooks, A.C. (2004). The Effects of Public Policy on Private Charity. Administration \& Society, 36(2), 166-185.

CAF (2017). CAF World Giving Index 2017: A global view of giving trends. West Malling: CAF. CSCSNS (2010). Population survey. Moscow, Russia: Centre for Studies of Civil Society and the Nonprofit Sector of the National Research University Higher School of Economics. CSGVP (2004). Canada Survey of Giving, Volunteering, and Participating 2004. Toronto, Canada: Statistics Canada.

Day, K.M. and Devlin, R.A. (1996). Volunteerism and Crowding out: Canadian Econometric Evidence. The Canadian Journal of Economics / Revue canadienne d'Economique, 29(1), 37-53. 
De Wit, A. (2016). Mechanisms of crowding-out and crowding-in: Private contributions in 20 European welfare states. In: Meuleman, R., Kraaykamp, G. and Wittenberg, M. (Eds.) Nederland in context: verschillen en overeenkomsten. Proceedings vijfde Nederlandse Workshop European Social Survey. Den Haag: DANS, pp. 121-146.

De Wit, A. and Bekkers, R. (2017). Government Support And Charitable Donations: A MetaAnalysis of the Crowding-out Hypothesis. Journal of Public Administration Research and Theory, 27(2), 301-319.

De Wit, A., Bekkers, R. and Broese Van Groenou, M. (2017). Heterogeneity in Crowding-out: When Are Charitable Donations Responsive To Government Support? European Sociological Review, 33(1): 59-71.

ENAFI. (2005). Encuesta Nacional De Filantropía (ENAFI) [National Survey on Philanthropy] 2005. Project on Philanthropy and Civil Society. Mexico: ITAM.

Einolf, C. (2017). Cross-National Differences in Charitable Giving in the West and the World. VOLUNTAS: International Journal of Voluntary and Nonprofit Organizations, 28(2), $472-491$.

ESS (2002): European Social Survey, Round 1 Data (2002). Data file edition 6.4. Norwegian Social Science Data Services, Norway - Data Archive and distributor of ESS data.

European Commission (2012). Eurobarometer 62.2 (Nov-Dec 2004). TNS Opinion \& Social, Brussels [Producer]. GESIS Data Archive, Cologne. ZA4231, Data file Version 1.1.0,doi:10.4232/1.10964.

Gesthuizen, M., Van der Meer, T. and Scheepers, P. (2008). Education and Dimensions of Social Capital: Do Educational Effects Differ due to Educational Expansion and Social Security Expenditure? European Sociological Review, 24(5), 617-632. 
GINPS05 (2006). Giving in the Netherlands Panel Study 2005. [machine-readable data file]. Wiepking, Pamala, Bekkers, René, Schuyt, Theo N.M., Gouwenberg, Barbara M. [principle investigator(s)]. Amsterdam: VU University, Philanthropic Studies [distributor]. Giving France (2009). Giving France. [machine-readable data file]. Wiepking, Pamala [principle investigator]. Amsterdam: VU University, Philanthropic Studies [distributor].

Hall, Michael H. 2001. "Measurement Issues in Surveys of Giving and Volunteering and Strategies Applied in the Design of Canada's National Survey of Giving, Volunteering and Participation." Nonprofit and Voluntary Sector Quarterly 30:515-526.

Handy, F. (2000). How We Beg: The Analysis of Direct Mail Appeals. Nonprofit and Voluntary Sector Quarterly, 29(3), 439-454.

Haski-Leventhal, D., Katz, H. and Yogev-Keren, H., (2011). Philanthorpy in Israel 2008: Pattern of Volunteering, Giving and Organ Donations. Beersheba: Ben-Gurion University of the Negev, Israeli Center for Third Sector Research.

HBS. (2005). Household Budget Survey, 2005. [dataset]. Dublin, Ireland: Irish Social Science Data Archive. Accessed via the Irish Social Science Data Archive - www.ucd.ie/issda. Hughes, P.N. and Luksetich, W.A. (1999). The Relationship Among Funding Sources for Art and History Museums. Nonprofit Management and Leadership, 10(1), 21-37.

IIPD (2016). Individual International Philanthropy Database [Machine-readable data file]. Wiepking P and Handy F [principle investigators]. Rotterdam, the Netherlands: Erasmus University Rotterdam [distributor].

Ingram, P. and Clay, K. (2000). The Choice-Within-Constraints New Institutionalism and Implications for Sociology. Annual Reviews of Sociology, 26, 525-546. 
Japan Fundraising Association. (2010). KifuHakusho 2010 [Giving Japan 2010]. Tokyo, Japan: Nihon Keidanren Suppan.

Kennedy, John M. and Brian Vargus. 2001. "Challenges in Survery Research and Their Implications for Philanthropic Studies Research." Nonprofit and Voluntary Sector Quarterly 30:483-494.Khanna, J., Posnett, J. and Sandler, T. (1995). Charity Donations in the UK: New Evidence Based on Panel Data. Journal of Public Economics, 56, 257-272.

Khanna, J. and Sandler, T. (2000). Partners in Giving:: The Crowding-in Effects of UK Government Grants. European Economic Review, 44(8), 1543-1556.

Kingma, B.R. (1989). An Accurate Measurement of the Crowd-out Effect, Income Effect, and Price Effect for Charitable Contributions. The Journal of Political Economy, 97(5), 11971207.

Kirsch, Arthur D., Michael T. McCormack, and Saxon-Harrold Susan K. E. 2001. "Evaluation of Differences in Giving and Volunteering Data Collected by In-Home and Telephone Interviewing." National Tax Journal 30:495-504.

Klamer, A. (2004). Art as a common good. Paper presented at the 13th conference of the Association of Cultural Economics International.

Künemund, H. and Rein, M. (1999). There Is More to Receiving than Needing: Theoretical Arguments and Empirical Explorations of Crowding In and Crowding Out. Ageing and Society, 19(01), 93-121.

Lecy, J.D. and Van Slyke, D.M. (2013). Nonprofit Sector Growth and Density: Testing Theories of Government Support. Journal of Public Administration Research and Theory, 23(1), $189-214$. 
Low, N., Butt, S., Ellis, P., \& Davis Smith, J. (2007). Helping Out: A national survey of volunteering and charitable giving. Retrieved at http://openaccess.city.ac.uk/2547/1/Helping\%20Out.pdf, August 22, 2017).

Lu, J. (2016). The Philanthropic Consequence of Government Grants to Nonprofit Organizations: A Meta-Analysis. Nonprofit Management and Leadership, 26(4), 381-400.

Lyons, M. and Passey, A. (2007). Giving Australia, Individual and Household Survey, 2005. Sydney, Australia: University of Technology.

Neumayr, M., and Schober, C. (2009). Ergebnisse einer repräsentativen Bevölkerungsbefragung zum Spendenverhalten in Österreich [Findings on giving in Austria from a representative population survey].Vienna, Austria: Vienna University of Economics and Business.

Nguyen, P.A. (2015). The Influence of Government Support for the Nonprofit Sector on Philanthropy across Nations. In: Handy, F. and Wiepking, P. (Eds.), The Palgrave Handbook of Global Philanthropy. Basingstoke: Palgrave Macmillan, pp. 530-539.

Okten, C. and Weisbrod, B.A. (2000). Determinants of Donations in Private Nonprofit Markets. Journal of Public Economics, 75(2), 255-272.

Payne, A.A. (1998). Does the Government Crowd-Out Private Donations? New Evidence From a Sample of Non-Profit Firms. Journal of Public Economics, 69(3), 323-345.

Payne, A.A. (2009). Does Government Funding Change Behavior? An Empirical Analysis of Crowd Out. In: Brown, J.R. and Poterba, J.M. (Eds.) Tax Policy and the Economy, pp. $159-184$.

Pennerstorfer, A. and Neumayr, M. (2017). Examining the Association of Welfare State Expenditure, Non-profit Regimes and Charitable Giving. VOLUNTAS: International Journal of Voluntary and Nonprofit Organizations, 28(2), 532-555. 
Petrovski, E. (2017). Whether and How Much to Give: Uncovering the Contrasting Determinants of the Decisions of Whether and How Much to Give to Charity with Two-Stage Alternatives to the Prevailing Tobit Model. VOLUNTAS: International Journal of Voluntary and Nonprofit Organizations, 28(2), 594-620.

Piantadosi, S., Byar, D.P. and Green, S.B. (1988). The Ecological Fallacy. American Journal of Epidemiology, 127(5), 893-904.

Roberts, R.D. (1984). A Positive Model of Private Charity and Public Transfers. Journal of Political Economy, 92(1), 136-148.

Rooney, Patrick, Kathryn Steinberg, and Paul Schervish. 2001. "A Methodological Comparison of Giving Surveys: Indiana as a Test Case." Nonprofit and Voluntary Sector Quarterly 30:551-568.

Rooney, P.M., Steinberg, K.S. and Schervish, P.G. (2004). Methodology is Destiny: The Effect of Survey Prompts on Reported Levels of Giving and Volunteering. Nonprofit and Voluntary Sector Quarterly, 33(4), 628-654.

Rose-Ackerman, S. (1981). Do Government Grants to Charity Reduce Private Donations? In: White, M. (Ed.), Nonprofit Firms in a Three Sector Economy. Washington: The Urban Institute, pp. 95-114.

Rothstein, B. (1998). Just Institutions Matter: The Moral and Political Logic of the Universal Welfare State. Cambridge: Cambridge University Press.

Schiff, J. (1990). Charitable Giving and Government Policy: An Economic Analysis. Westport, Connecticut: Greenwood Press. 
Salamon, L.M. and Anheier, H.K. (1998). Social origins of civil society: Explaining the nonprofit sector cross-nationally. VOLUNTAS: International Journal of Voluntary and Nonprofit Organizations, 9(3), 213-248.

SOEP (2011). Data for years 1984 - 2010. Doi: 10.5684/soep.v27.

Sokolowski, S.W. (2013). Effects of Government Support of Nonprofit Institutions on Aggregate Private Philanthropy: Evidence from 40 Countries. VOLUNTAS: International Journal of Voluntary and Nonprofit Organizations, 24(2), 359-381.

Stadelmann-Steffen, I. (2011). Social Volunteering in Welfare States: Where Crowding Out Should Occur. Political Studies, 59(1), 135-155.

Strauss, J., Witoelar, F., Sikoki, B. and Wattie, A.M. (2009). The Fourth Wave of the Indonesian Family Life Survey (IFLS4): Overview and Field Report. WR-675/1-NIA/NICHD.

Suanet, B., Broese Van Groenou, M. and Van Tilburg, T. (2012). Informal and Formal HomeCare Use among Older Adults in Europe: Can Cross-national Differences be Explained by Societal Context and Composition? Ageing and Society, 32(3), 491-515.

Stadelmann-Steffen, I., Freitag, M. and Bühlmann, M. (2007). Freiwilligenmonitor 2007. Zürich, Switzerland: Seismo.

Thaler, R.H. (1999). Mental Accounting Matters. Journal of Behavioral Decision Making, 12(3), 183-206.

The Beautiful Foundation (2006). Giving Korea 2006. Seoul, Korea: The Beautiful Foundation. TSCS (2009). Taiwan Social Change Survey. Questionnaire II, phase 5, wave 5. Taipei, Taiwan: Center for Survey Research, Academia Sinica.

Tukey, J.W. (1962). The Future of Data Analysis. The Annals of Mathematical Statistics, 33, 167. 
Vamstad, J. and Von Essen, J. (2013). Charitable Giving in a Universal Welfare State: Charity and Social Rights in Sweden. Nonprofit and Voluntary Sector Quarterly, 42(2), 285-301.

Van Oorschot, W. and Arts, W. (2005). The Social Capital of European Welfare States: The Crowding Out Hypothesis Revisited. Journal of European Social Policy, 15(1), 5-26.

Van Tubergen, F., Maas, I. and Flap, H. (2004). The economic incorporation of immigrants in 18 western societies: Origin, destination, and community effects. American Sociological Review, 69(5), 704-727.

Wagner, G.G., Göbel, J., Krause, P., Pischner, R. and Sieber, I. (2008). Das Sozio-oekonomische Panel (SOEP): Multidisziplinäres Haushaltspanel und Kohortenstudie für Deutschland Eine Einführung (für neue Datennutzer) mit einem Ausblick (für erfahrene Anwender), AStA Wirtschafts- und Sozialstatistisches Archiv, 2(4), 301-328.

Warr, P.G. (1982). Pareto Optimal Redistribution and Private Charity. Journal of Public Economics, 19(1), 131-138.

Wiepking, P., \& Handy, F. (2016). Documentation Individual International Philanthropy Database (IIPD). A Comparative Study of Global Giving. 19 country IIPD. Version 1. Rotterdam, the Netherlands: Erasmus University Rotterdam. Retrieved at December 2, 2017 from http://www.wiepking.com/papers/Documentation_IIPD_(2016_version1).pdf.

Wilhelm, M.O., Brown, E., Rooney, P.M. and Steinberg, R. (2005). The Center on Philanthropy Panel Study [Data file]. Ann Arbor, MI: Institute for Social Research, The University of Michigan.

Wilhelm, Mark O. 2007. "The Quality and Comparability of Survey Data on Charitable Giving." Nonprofit and Voluntary Sector Quarterly 36:65-84. 
Wollebæk, D. and Sivesind, K.H. (2010). Fra folkebevegelse til filantropi? Frivillig innsats $i$ Norge 1997-2009 [From popular movement to philanthropy? Volunteering in Norway 1997-2009]. Oslo, Norway: Senter for forskning på sivilsamfunn og frivillig sektor.

Young, D.R. (2000). Alternative Models of Government-Nonprofit Sector Relations: Theoretical and International Perspectives. Nonprofit and Voluntary Sector Quarterly, 29(1), 149-172. 
Figure 1: Average philanthropic donations and government expenditures (Sources: IIPD, IMF)
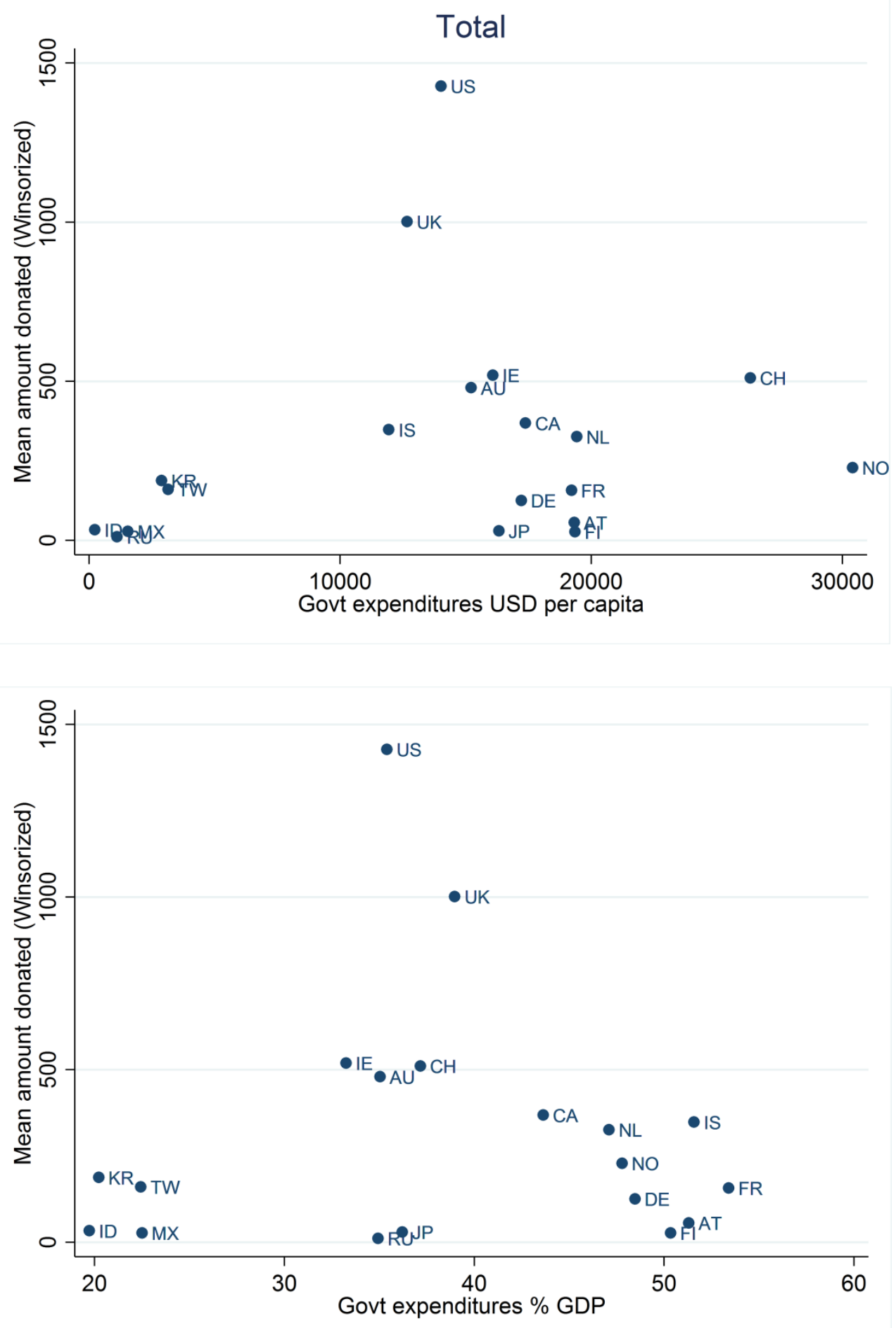

Figure 2: Average philanthropic donations and government expenditures per sector 

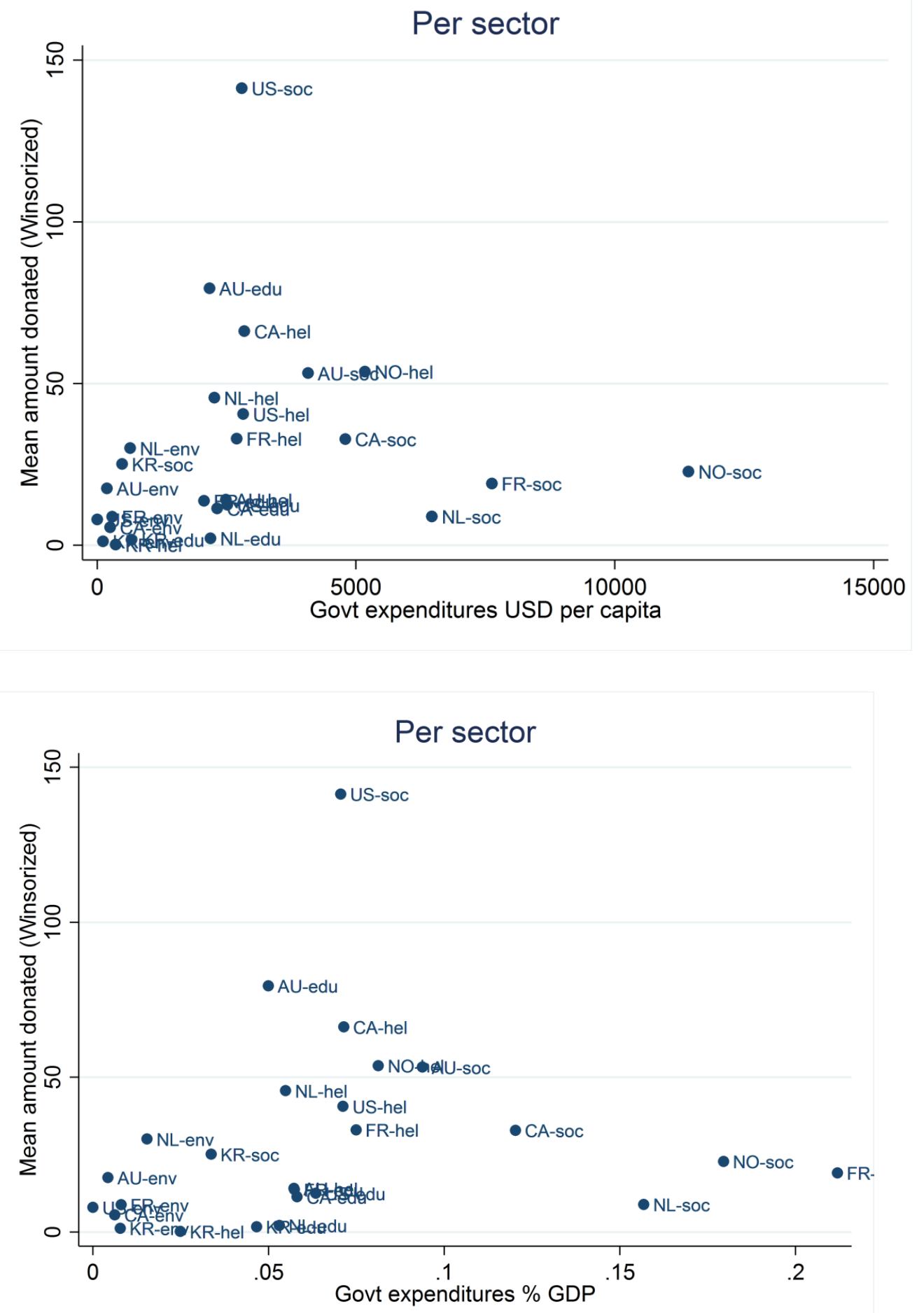
Figure 3: Average philanthropic donations per sector and government expenditures to social protection and health
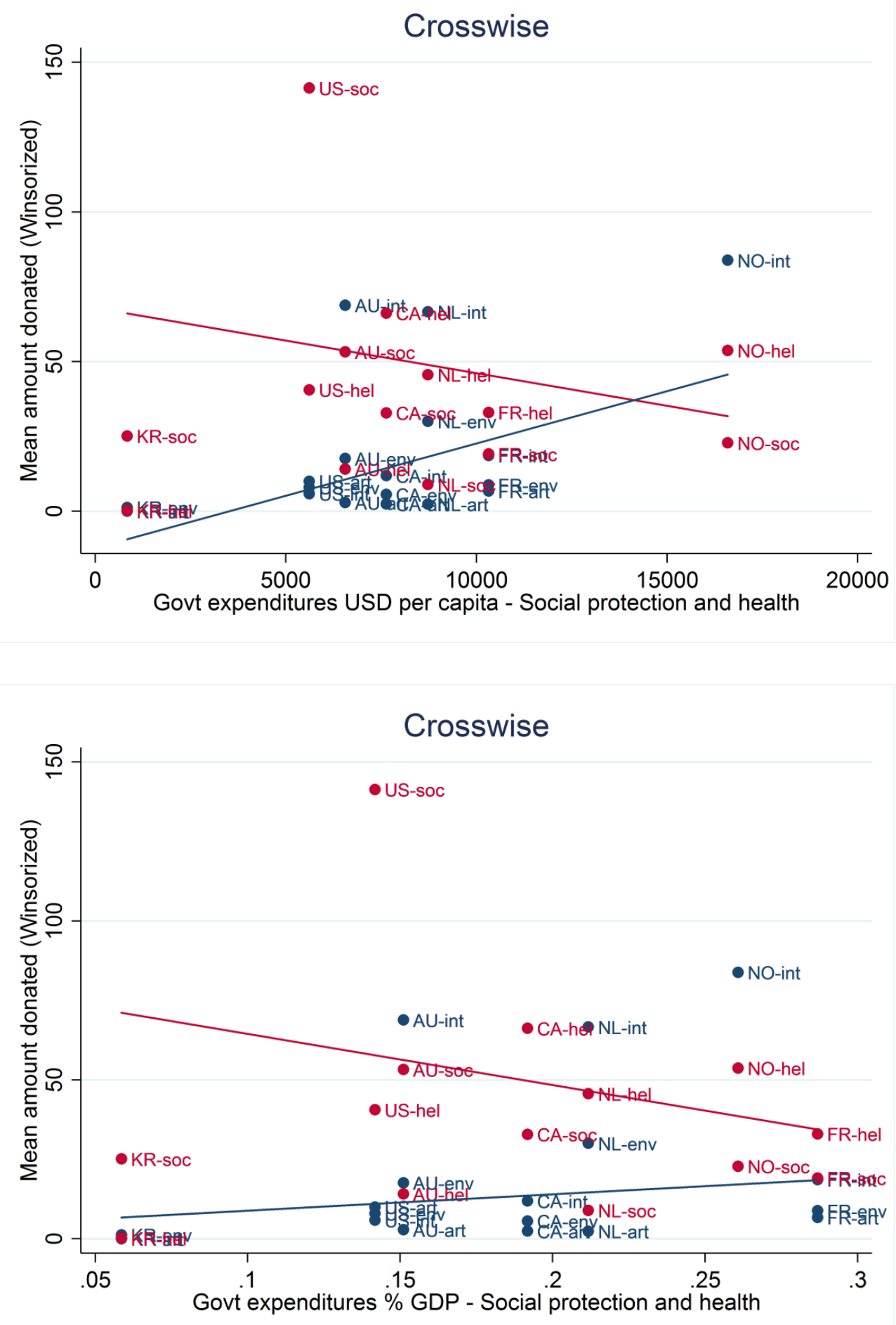
Table 1: Descriptive statistics

Donated

Amount donated

Donated to environment

Amount donated to environment

Donated to education

Amount donated to education

Donated to social services

Amount donated to social services

Donated to health

Amount donated to health

Donated to arts and culture

Amount donated to arts and culture

Donated to international aid

Amount donated to international aid

Government expenditures per capita $/ 1,000$

Government environment expenditures per capita $/ 1,000$

Government education expenditures per capita $/ 1,000$

Government social protection expenditures per capita /1,000

Government health expenditures per capita /1,000

$\mathrm{N}$

126,923

72,076

41,911

4,687

40,158

10,686

43,848

17,735

43,294

18,850

40,158

1,824

42,649

5,271

126,923

111,524

111,524

111,524

111,524

126,923

126,923

126,923

126,923

126,923

126,923

126,923

126,923
Mean

0.631

549.757

0.144

109.239

0.286

143.459

0.474

147.015

0.480

115.130

0.055

224.786

0.154

229.057

10.858

0.196

1.542

3.987

1.875
SD

0.483

2808.784

0.352

473.764

0.452

774.312

0.499

760.573

0.500

409.878

0.229

1605.350

0.361

522.562

8.600

0.194

1.122

3.050

1.325
Max

293800.000

24794.000

35997.620

47713.290

1

16435.340

1

61985.000

17259.980

30.403

0.636

3.903

11.422

5.170

Education: low

Education: middle

Male

Married

19.638
45.765
0.285
0.475
0.289
0.489
0.601
3.737

14.656
16.593
0.452
0.499
0.453
0.500
0.490
5.115

0.975

49.095

100.000

1

1

1

3.737

659.956 
Table 2: Probit and Linear multilevel regression models on total giving (Sources: IIPD, IMF, OECD)

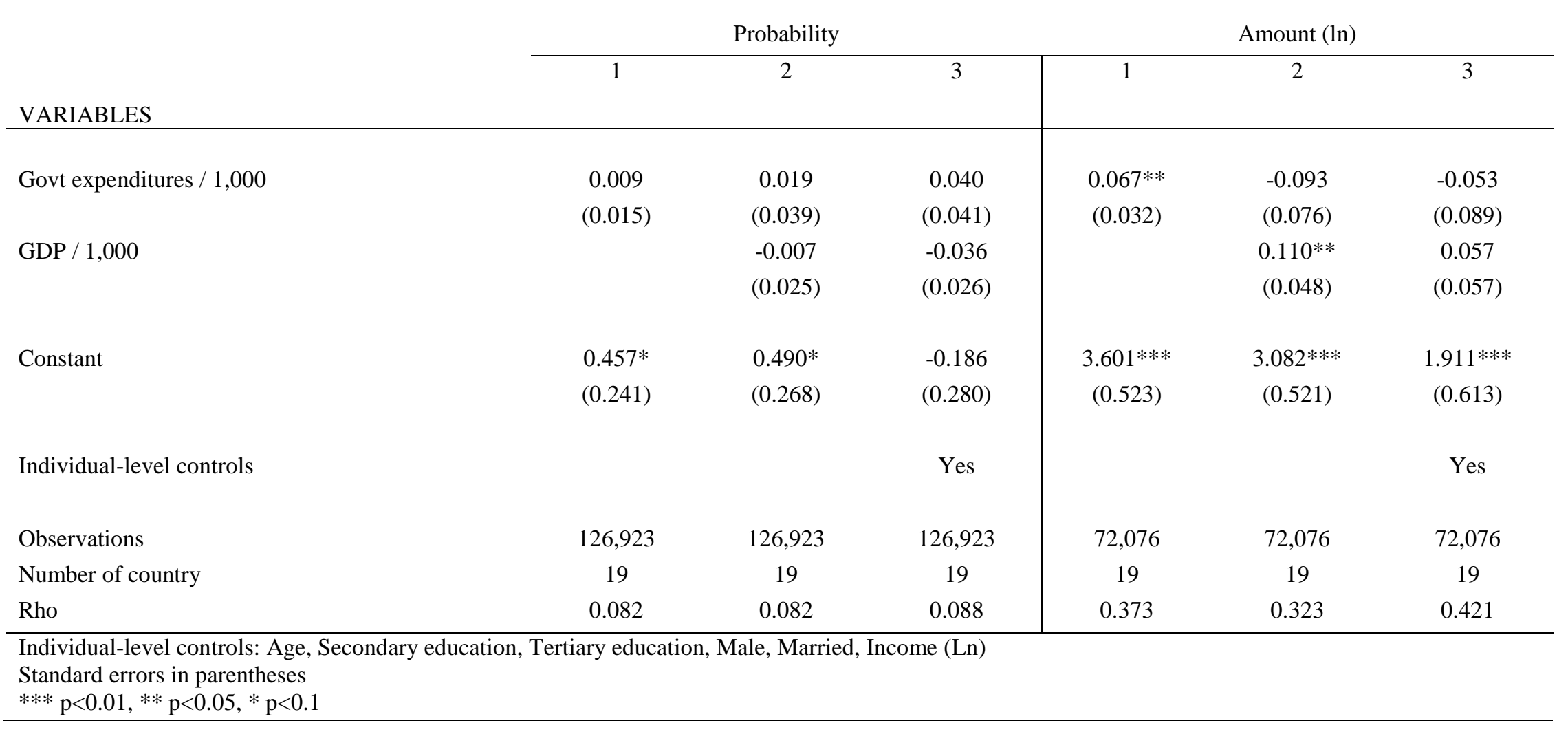


Table 3: Probit and Linear multilevel regression models on giving to fields of welfare (Sources: IIPD, IMF, OECD)

\begin{tabular}{|c|c|c|c|c|c|c|c|c|}
\hline & \multicolumn{4}{|c|}{ Probability } & \multicolumn{4}{|c|}{ Amount (ln) } \\
\hline VARIABLES & 1 & 2 & 3 & 4 & 1 & 2 & 3 & 4 \\
\hline Govt expenditures per sector $/ 1,000$ & $\begin{array}{c}0.127 * * * \\
(0.043)\end{array}$ & $\begin{array}{c}0.120 * * \\
(0.056)\end{array}$ & $\begin{array}{c}0.129 * * \\
(0.059)\end{array}$ & $\begin{array}{c}2.700 * * * \\
(0.535)\end{array}$ & $\begin{array}{l}-0.022 \\
(0.055)\end{array}$ & $\begin{array}{l}-0.087 \\
(0.063)\end{array}$ & $\begin{array}{l}-0.068 \\
(0.071)\end{array}$ & $\begin{array}{l}-1.453 \\
(1.741)\end{array}$ \\
\hline Sector: Environment & & & & ref & & & & Ref \\
\hline Sector: Education & & & & $\begin{array}{l}-1.050 \\
(1.283)\end{array}$ & & & & $\begin{array}{c}1.367 \\
(1.634)\end{array}$ \\
\hline Sector: Health & & & & $\begin{array}{c}0.461 \\
(0.500)\end{array}$ & & & & $\begin{array}{l}-0.363 \\
(0.878)\end{array}$ \\
\hline Sector: Social services & & & & $\begin{array}{c}1.852 * * * \\
(0.566)\end{array}$ & & & & $\begin{array}{l}-0.357 \\
(1.107)\end{array}$ \\
\hline Education * Govt expenditures / 1,000 & & & & $\begin{array}{c}-1.913 * * \\
(0.815)\end{array}$ & & & & $\begin{array}{c}0.594 \\
(1.871)\end{array}$ \\
\hline Health * Govt expenditures / 1,000 & & & & $\begin{array}{c}-2.435 * * * \\
(0.541)\end{array}$ & & & & $\begin{array}{c}1.382 \\
(1.741)\end{array}$ \\
\hline Social $*$ Govt expenditures / 1,000 & & & & $\begin{array}{c}-2.741 * * * \\
(0.536)\end{array}$ & & & & $\begin{array}{c}1.409 \\
(1.763)\end{array}$ \\
\hline GDP / 1,000 & & $\begin{array}{c}0.004 \\
(0.010)\end{array}$ & $\begin{array}{c}0.129 \\
(0.059)\end{array}$ & $\begin{array}{l}-0.003 \\
(0.016)\end{array}$ & & $\begin{array}{l}0.034 * \\
(0.018)\end{array}$ & $\begin{array}{c}0.017 \\
(0.020)\end{array}$ & $\begin{array}{c}0.023 \\
(0.029)\end{array}$ \\
\hline Constant & $\begin{array}{c}-0.905^{* * *} \\
(0.114)\end{array}$ & $\begin{array}{c}-1.005 * * * \\
(0.187)\end{array}$ & $\begin{array}{c}-1.601 * * * \\
(0.446)\end{array}$ & $\begin{array}{c}-2.234 * * * \\
(0.437)\end{array}$ & $\begin{array}{c}3.878 * * * \\
(0.210)\end{array}$ & $\begin{array}{c}3.082 * * * \\
(0.455)\end{array}$ & $\begin{array}{c}1.919 * * * \\
(0.505)\end{array}$ & $\begin{array}{c}2.052 * * \\
(0.926)\end{array}$ \\
\hline Individual-level controls & & & Yes & Yes & & & Yes & Yes \\
\hline
\end{tabular}


Observations

Number of country-sector

Number of respondents

Rho

Individual-level controls: Age, Secondary education, Te

Standard errors in parentheses. $* * * \mathrm{p}<0.01, * * \mathrm{p}<0.05, * \mathrm{p}<0.1$

\begin{tabular}{cccc|cccc}
157,392 & 157,392 & 157,392 & 157,392 & 49,725 & 49,725 & 49,725 & 49,725 \\
39 & 39 & 39 & 39 & 26 & 26 & 26 & 26 \\
40,899 & 40,899 & 40,899 & 40,899 & 27,453 & 27,453 & 27,453 & 27,453 \\
0.177 & 0.177 & 0.177 & 0.132 & 0.225 & 0.196 & 0.208 & 0.242 \\
\hline
\end{tabular}


Table 4: Probit and Linear multilevel regression models on giving to environment, arts and culture, and international aid (Sources: IIPD, IMF, OECD)

\begin{tabular}{|c|c|c|c|c|c|c|}
\hline & \multicolumn{3}{|c|}{ Probability } & \multicolumn{3}{|c|}{ Amount $(\ln )$} \\
\hline VARIABLES & 1 & 2 & 3 & 1 & 2 & 3 \\
\hline Social protection and health expenditures / 1,000 & $\begin{array}{c}0.154 * * * \\
(0.030)\end{array}$ & $\begin{array}{l}0.108 * \\
(0.057)\end{array}$ & $\begin{array}{c}0.146 * * * \\
(0.056)\end{array}$ & $\begin{array}{l}-0.032 \\
(0.055)\end{array}$ & $\begin{array}{l}-0.077 \\
(0.067)\end{array}$ & $\begin{array}{l}-0.016 \\
(0.046)\end{array}$ \\
\hline GDP / 1,000 & & $\begin{array}{c}0.026 \\
(0.020)\end{array}$ & $\begin{array}{c}0.011 \\
(0.023)\end{array}$ & & $\begin{array}{c}0.031 \\
(0.026)\end{array}$ & $\begin{array}{c}0.014 \\
(0.018)\end{array}$ \\
\hline Age & & & $\begin{array}{c}0.006 * * * \\
(0.000)\end{array}$ & & & $\begin{array}{r}0.010^{* * *} \\
(0.001)\end{array}$ \\
\hline Constant & $\begin{array}{c}-2.342 * * * \\
(0.239)\end{array}$ & $\begin{array}{c}-2.695 * * * \\
(0.302)\end{array}$ & $\begin{array}{c}-3.193 * * * \\
(0.434)\end{array}$ & $\begin{array}{c}4.326^{* * * *} \\
(0.469)\end{array}$ & $\begin{array}{c}3.778 * * * \\
(0.664)\end{array}$ & $\begin{array}{r}2.497 * * * \\
(0.477)\end{array}$ \\
\hline Individual-level controls & & & Yes & & & Yes \\
\hline Observations & 115,825 & 115,825 & 115,825 & 11,245 & 11,245 & 11,245 \\
\hline Number of Country-sector combinations & 28 & 28 & 28 & 17 & 17 & 17 \\
\hline Number of respondents & 40,899 & 40,899 & 40,899 & 9,180 & 9,180 & 9,180 \\
\hline Rho & 0.123 & 0.119 & 0.115 & 0.175 & 0.169 & 0.181 \\
\hline
\end{tabular}

Individual-level controls: Age, Secondary education, Tertiary education, Male, Married, Income (Ln) Standard errors in parentheses. $* * * \mathrm{p}<0.01, * * \mathrm{p}<0.05, * \mathrm{p}<0.1$ 